\title{
SISTEM PENDUKUNG KEPUTUSAN PEMILIHAN LOKASI SISTEM PENDUKUNG KEPUTUSAN REKOMENDASI ANGGOTA CALON PASKIBRAKA MENGGUNAKAN METODE TOPSIS
}

\author{
Vita Alviana ${ }^{1}$, Ely Setyo Astuti ${ }^{2}$, Rosa Andrie Asmara ${ }^{3}$ \\ ${ }^{1,2,3}$ Program Studi Teknik Informatika, Jurusan Teknologi Informasi, Politeknik Negeri Malang. \\ vita.alvi@gmail.com, ${ }^{2}$ ely.setyo.astuti@polinema.ac.id, ${ }^{3}$ rosaandrie@gmail.com
}

\begin{abstract}
Abstrak
Penilaian pada Rekomendasi Pemilihan Anggota Paskibraka Masih menggunakan cara yang manual sehingga pengambilan keputusan untuk pemilihan membutuhkan waktu yang lama. Anggota calon Pakibraka dipilih melalui penilaian yang akan dilakukan secara terkomputerisasi dengan penilaian kriteria pada setiap siswa-siswi. Metode yang digunakan pada sistem pendukung keputusan ini adalah metode TOPSIS (Technique for Order Preference by Similarity to Ideal Solution). Metode TOPSIS merupakan salah satu metode pengambilan keputusan untuk menentukan pilihan terbaik yang mendekati dari kriteria-kriteria tertentu dan meyelesaikan masalah keputusan secara efisien. Selain itu data dari tiap seleksi lebih terjaga keamananya dan tidak mudah hilang dan juga bisa di report dari sistem di setiap data yang ada. Hasil dari sistem aplikasi ini berupa tabel perangkingan setiap siswa dari seleksi pertama dan terakhir untuk mengetahui anggota yang berhasil ataupun tidak dalam pemilihan anggota paskibraka di tingkat Kota. Dari data yang diuji coba nilai persentase kesamaan nilai sebesar 93\% dimana terdapat 3 siswa yang memiliki nila tidak sama. Perbedaanya ada pada pembulatan bilangan pecahan dalam sistem.
\end{abstract}

Kata kunci : Penilaian, Sistem Pendukung Keputusan, TOPSIS.

\section{Pendahuluan}

\subsection{Latar Belakang}

Setiap tahun Dinas Pendidikan Kota Malang akan menyeleksi Pasukan Pengibar Bendera Pusaka (Paskibraka) untuk memperingati hari ulang tahun kemerdekaan RI. Siswa-Siswi yang lolos di sekolah masing-masing yang akan di panggil untuk mengikuti seleksi di dinas pendidikan. Seleksi Paskibraka dilakukan untuk mempermudah dalam memilih calon anggota Paskibraka di tingkat kota kemudian melanjutkan proses seleksi di tingkat propinsi Dinas Kepemudaan dan Olahraga. Selain kondisi fisik dan kesehatan calon anggota Paskibraka juga harus memiliki jiwa nasionalisme, wawasan, pengetahuan, keterampilan dan kedisiplinan. Oleh sebab itu penyeleksian anggota dalam Paskibraka ini sangat penting dan diharapkan calon anggota Paskibraka nantinya yang berhasil lolos seleksi ini membawa nama sekolah, daerah dan bangsa.

Sebuah sistem yang mampu membantu dalam memecahkan masalah dengan kondisi semi terstruktur dan tak terstruktur sedangkan metode TOPSIS yaitu untuk menghitung bobot kriteria didasarkan pada konsep dimana alternatif terpilih yang terbaik tidak hanya memiliki jarak terpendek dari solusi ideal positif, namun juga memiliki jarak terpanjang dari solusi ideal negatif.

Dengan metode TOPSIS (Technique for Order Preference by Similarity to Ideal Solution) yang dapat membantu mengukur keberhasilan calon anggota Paskibraka di kota malang dengan beberapa bobot kriteria yang nantinya akan diproses dengan beberapa penilaian yang akan dilakukan di Dinas Pendidikan Kota Malang.

\subsection{Rumusan Masalah}

a. Bagaimana mengembangkan sistem pendukung keputusan dalam pemilihan anggota Paskibraka di Kota Malang untuk tingkat Kota?

b. Bagaimana Mengimplementasikan metode TOPSIS dalam pemilihan anggota Paskibraka di kota Malang? 
c. Bagaimana menghitung tingkat keberhasilan sistem pendukung keputusan rekomendasi anggota Paskibraka dengan menggunakan metode TOPSIS?

\subsection{Batasan Masalah}

1. Kriteria yang digunakan adalah kriteria yang didapatkan dari wawancara yang sudah menjadi ketentuan dari pihak Dinas Pendidikan untuk pemilihan anggota Paskibraka. Kriteria yang digunakan adalah kriteria dalam pemilihan anggota Paskibraka, kriteria-kriteria tersebut antara lain:
a. Kesehatan
b. Jasmani
c. PBB(Praktek Baris Berbaris)
d. Kepaskibrakaan
e. Pengetahuan Umum
f. Kepribadian

2. Data yang digunakan dalam mengambil keputusan adalah data pemilihan anggota Paskibraka untuk tingkat kota dari PPI (Purna Paskibraka Indonesia) khususnya di daerah malang.

\section{Landasan Teori}

\subsection{Sistem Pendukung Keputusan (SPK)}

Sistem pendukung keputusan (SPK) adalah bagian dari sistem informasi berbasis komputer (termasuk sistem pengetahuan) yang dipakai untuk mendukung pengambilan keputusan dalam suatu organisasi atau perusahaan. SPK merupakan penggabungan sumber-sumber kecerdasan individu dengan kemampuan komponen untuk memperbaiki kualitas keputusan.

\subsection{Metode TOPSIS}

TOPSIS adalah salah satu metode pengambilan keputusan multi criteria yang pertama kali diperkenalkan oleh Yonn dan Hwang (1981) dengan ide dasarnya adalah bahwa alternative yang dipilih memiliki jarak terdekat dengan solusi ideal positif dan memiliki jarak terjauh dari solusi ideal negative. Berikut ini merupakan langkah penyelesaian dari Sistem Pendukung Keputusan Rekomendasi anggota Paskibraka

1. Membuat matriks keputusan yang ternormalisasi

2. Membuat matriks keputusan yang ternormalisasi terbobot

3. Menentukan matriks solusi ideal positif dan solusi ideal negative
4. Menghitung separation measure

5. Menentukan jarak antara nilai setiap alternative dengan matriks solusi ideal positif dan negative

6. Menentukan nilai preferensi untuk setiap alternatif

\section{Metodologi}

\subsection{Analisa Sistem}

Dalam pemilihan anggota Paskibraka menggunakan 2 seleksi yaitu seleksi pertama (kesehataa dan jasmani) dan seleksi 2 (PBB, kepaskibrakaan, pengetahuan umum dan kepribadian) dari kriteria seleksi tersebut akan diberikan penilaian oleh pihak panitia dari bidang PPI (Purna Paskibraka Indonesia) di Kota Malang.

Tabel 1 Nilai Range

\begin{tabular}{|c|l|l|l|}
\hline Nilai & \multicolumn{3}{|c|}{ Keterangan Nilai } \\
\hline 5 & Sangat Baik & Sangat setuju & Selalu \\
\hline 4 & Baik & Setuju & Sering \\
\hline 3 & Biasa & Ragu - ragu & Kadang - kadang \\
\hline 2 & Tidak Baik & Tidak setuju & Jarang \\
\hline 1 & Sangat Tidak Baik & Sangat Tidak Setuju & Tidak Pernah \\
\hline
\end{tabular}

Keterangan:

C1: Kesehatan(I)

C2: Jasmani (I)

C3: PBB (II)

C4: Kepaskibrakaan (II)

C5: Pengetahuan Umum (II)

C6: Kepribadian (II)

\section{Perancangan}

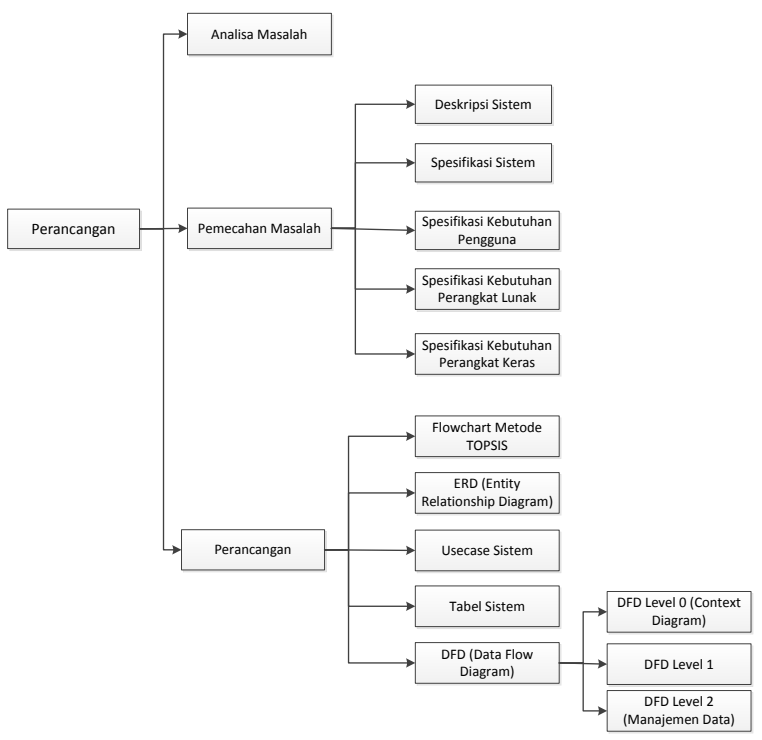

Gambar 1. Perancangan Sistem 


\subsection{Analisa Masalah}

Prosesnya setelah siswa melakukan tes dari masing-masing penjurian yang akan dilakukan biasanya masih dalam bentuk manual, panitia biasanya masih menggunakan kertas untuk sistem penilaian, oleh karena itu dengan adanya sistem ini penilaian dilakukan oleh panitia langsung melalui sistem yang akan di konfigurasi oleh admin untuk pemilihan siswa sebagai anggota Paskibraka.

\section{Implementasi}

\section{a. Tampilan Interface}

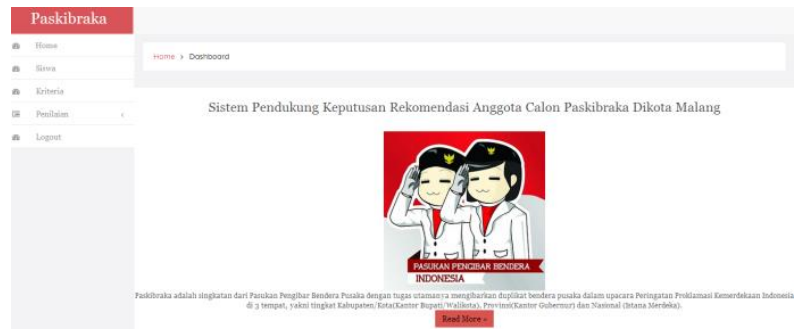

Gambar 2. Tampilan Awal Sistem

\section{b. Tampilan Input Data Siswa (Admin)}

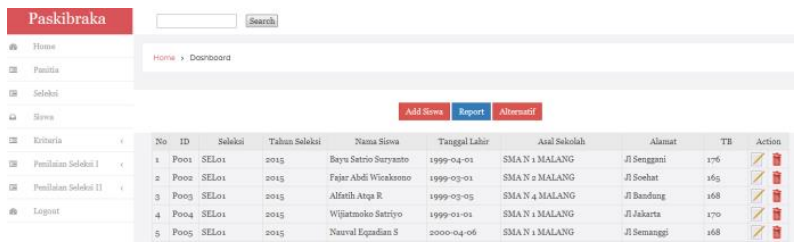

Gambar 3. Tampilan Input Siswa

Setelah login admin dapat melakukan pengisian data siswa sesuai dengan daftar siswa yang mendaftar, dihalaman data siswa admin dapat menambah, manghapus, merubah dan report siswa untuk penunjang kebutuhan panitia dalam memberikan penilaian.

\section{c. Tampilan Data Kriteria}

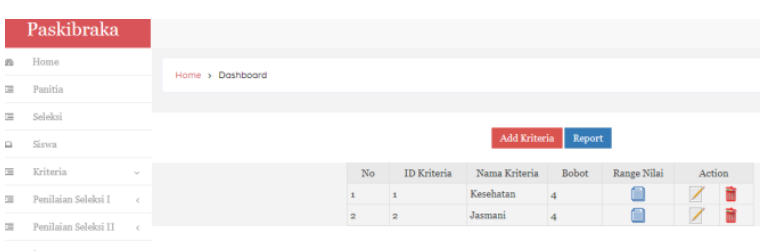

Gambar 4. Data Kriteria

Data kriteria yang telah ditentukan sebelumnya untuk penilaian seleksi I admin dapat menambah, menghapus, merubah data dan mengubah range setiap kriteria untuk penilaian setiap siswa.

\section{d. Tampilan Penilaian Panitia}

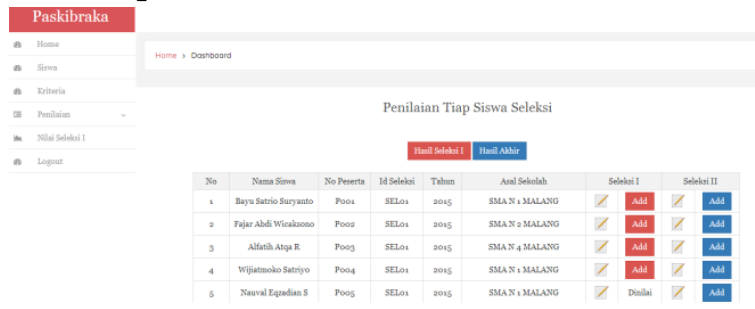

Gambar 5. Tampilan Penilaian

Panitia dapat mengisikan nilai yang sudah disediakan diatas dengan mengklik button add pada kolom seleksi I maka akan keluar halaman dimana terdapat range penilaian yang sudah disediakan. Dan langkah yang sama dilakukan panitia untuk seleksi II.

\section{Uji Coba Dan Pembahasan 6.1 Proses Uji Coba Perhitungan}

Berikut ini merupakan nilai alternatif dari data siswa membentuk matriks penilaian alternatif Ditunjukan pada tabel 3 dan tabel 4 dibawah ini:

a. Menentukan matriks penilaian alternatif

Tabel 2. Nama Siswa

\begin{tabular}{|l|l|}
\hline Asal sekolah & Nama Siswa \\
\hline SMA TAMAN MADYA & Bayu Prakoso Suryanto \\
\hline SMA N 4 MALANG & Alfatih Atqa R \\
\hline SMA N 1 MALANG & Wijiatmoko Satriyo \\
\hline SMA TAMAN HARAPAN & Immanuel Rico \\
\hline SMK TELKOM MALANG & Alvian Ghuslal \\
\hline
\end{tabular}

Keterangan:

Siswa 1 = Bayu Prakoso Suryanto

Siswa 2 = Alfatih Atqa R

Siswa 3 = Wijiatmoko Satriyo

Siswa 4 = Immanuel Rico

Siswa 5 = Alvian Ghuslal

$\mathrm{C}=$ Kriteria Penilaian

Tabel 3. Nilai Seleksi

\begin{tabular}{|c|c|c|}
\hline Alternatif & Cl & C2 \\
\hline Siswa 1 & 4 & 4 \\
\hline Siswa 2 & 4 & 3 \\
\hline Siswa 3 & 4 & 3 \\
\hline Siswa 4 & 4 & 4 \\
\hline Siswa 5 & 3 & 4 \\
\hline
\end{tabular}


b. Menentukan Normalisasi Matriks

Dengan menggunakan persamaan dari penilaian alternative diatas maka hasil matriks yang diproses pada seleksi I seperti tabel 4.

Tabel 4. Normalisasi Matriks

\begin{tabular}{|c|c|c|}
\hline Alternatif & C1 & C2 \\
\hline Siswa 1 & 0,20879 & 0,83519 \\
\hline Siswa 2 & 0,15659 & 0,62639 \\
\hline Siswa 3 & 0,15659 & 0,62639 \\
\hline Siswa 4 & 0,15936 & 0,65745 \\
\hline Siswa 5 & 0,11952 & 0,47809 \\
\hline
\end{tabular}

c. Menentukan Matriks Ternormalisasi Terbobot

Berikut ini merupakan matriks ternormalisasi dengan menggunakan persamaan matriks seperti tabel 5.

Tabel 5 Normalisasi Matriks Terbobot

\begin{tabular}{|c|c|c|}
\hline Alternatif & C1 & C2 \\
\hline Siswa 1 & 0,20879 & 0,83519 \\
\hline Siswa 2 & 0,15659 & 0,62639 \\
\hline Siswa 3 & 0,15659 & 0,62639 \\
\hline Siswa 4 & 0,15936 & 0,65745 \\
\hline Siswa 5 & 0,11952 & 0,47809 \\
\hline
\end{tabular}

d. Menentukan Solusi Ideal Positif dan Negatif

Berikut ini merupakan persamaan untuk menghitung matriks solusi ideal positif dan negative seperti pada tabel 6 dan table 7 .

Tabel 6 Solusi Ideal Positif

\begin{tabular}{|c|c|}
\hline C1 & C2 \\
\hline 0,20879 & 0,83519 \\
\hline
\end{tabular}

Tabel 7 Solusi Ideal Negatif

\begin{tabular}{|c|c|}
\hline $\mathbf{C 1}$ & $\mathbf{C 2}$ \\
\hline 0,11952 & 0,47809 \\
\hline
\end{tabular}

e. Menentukan jarak antar nilai alternatif dengan solusi ideal positif dan solusi ideal negative

Dengan menggunakan persamaan maka jarak antar nilai alternative dengan solusi ideal positif dan negatif dari ditunjukkan pada tabel 8 dan 9 .

Tabel 8. Jarak Solusi Positif

\begin{tabular}{|c|c|}
\hline Alternatif & Nilai \\
\hline Siswa 1 & 0,15939 \\
\hline Siswa 2 & 0,26266 \\
\hline Siswa 3 & 0,26266 \\
\hline Siswa 4 & 0,15936 \\
\hline Siswa 5 & 0,31872 \\
\hline
\end{tabular}

Tabel 9 Jarak Solusi Negatif

\begin{tabular}{|c|c|}
\hline Alternatif & Nilai \\
\hline Siswa 1 & 0,63479 \\
\hline Siswa 2 & 0,52169 \\
\hline Siswa 3 & 0,52169 \\
\hline Siswa 4 & 0,63479 \\
\hline Siswa 5 & 0,52533 \\
\hline
\end{tabular}

f. Menentukan Nilai Preferensi

Dengan menggunakan persamaan didapatkan nilai preferensi untuk setiap alternative ditunjukkan pada tabel 10 .

Tabel 10 Nilai Preferensi

\begin{tabular}{|c|c|}
\hline Alternatif & Nilai Preferensi \\
\hline Siswa 1 & 0,79932 \\
\hline Siswa 2 & 0,66512 \\
\hline Siswa 3 & 0,66512 \\
\hline Siswa 4 & 0,79932 \\
\hline Siswa 5 & 0,62238 \\
\hline
\end{tabular}

Dibawah ini merupakan hasil perangkingan dari hasil data nilai preferensi diatas dan juga untuk mengetahui siswa yang lolos dan yang tidak lolos dalam seleksi. Seperti ditunjukan pada tabel 11 .

Tabel 11 Hasil Perangkingan

\begin{tabular}{|c|c|c|}
\hline No & Alternatif & Nilai Preferensi \\
\hline 1 & Siswa 1 & 0,79932 \\
\hline 2 & Siswa 4 & 0,79932 \\
\hline 3 & Siswa 3 & 0,66512 \\
\hline 4 & Siswa 2 & 0,66512 \\
\hline 5 & Siswa 5 & 0,62238 \\
\hline
\end{tabular}

\section{Kesimpulan Dan Saran}

\subsection{Kesimpulan}

a. Pengembangan sistem pendukung keputusan pemilihan anggota calon paskibraka menggunakan metode TOPSIS yang dibangun sesuai dengan perancangan yang telah dibuat. Perancangan sistem dan model sistem pendukung keputusan didasarkan pada studi literature, pengumupan data dan analisa kebutuhan. 
b. Dapat digunakan sebagai salah satu cara untuk memepermudah dalam menentukan seleksi penerima anggota calon paskibraka. Sistem di implementasikan dengan menggunakan 6 kriteria masukan untuk proses perhitungan TOPSIS sebagai proses rekomendasi angota. Hasil keluaran sistem adalah rekomendasi pemilihan anggota calon paskibraka yang berupa perangkingan setiap siswa dalam penilaian.

\subsection{Saran}

Saran yang diberikan untuk pengembangan sistem dalam penelitian selanjutnya adalah:

a. Dapat dilakukan penelitian lebih lanjut dalam menentukan nilai minimum dalam proses perhitungan dengan menggunkan metode TOPSIS sehingga akurasi sistem menjadi lebih optimum.

b. Penambahan subjek penelitian dan studi kasus dengan subjek yang lebih besar dapat memberikan gambaran kasus yang lebih informatif.

c. Sistem dapat dikembangkan menjadi sebuah sistem yang bersifat lebih dinamis.

\section{Daftar Pustaka:}

Kusrini, (2007): Konsep Dan Aplikasi Sistem Pendukung Keputusan, STMIK AMIKOM, Yogyakarta.

Sinaga, R., (2014): Sistem Pendukung Keputusan Dalam Menyeleksi Anggota Paskibraka Dengan Metode Simple Additive Weighting (SAW) Pada Kantor Dinas Pemuda dan Olahraga Kab Simalungun, STMIK Budidarma, Medan.

Riadi, M., (2013): Pengertian Sistem

Pendukung Keputusan, [Online]

Tersedia:

http://www.kajianpustaka.com/2013/09/sis tem-pendukung-keputusan-spk.html,

[2 Desember 2015]

Murnawan, A. F. S., (2012): Sistem Pendukung Keputusan Menggunakan Metode Technique for Order by Similarity to Ideal Solution (TOPSIS), Jurnal Sistem Informasi (JSI) Fakultas Ilmu Komputer Universitas Sriwijaya, VOL. 4, NO. 1, April 2012.

Sparague, R. H. \& Watson H. J., (1993): Decision Support Systems: Putting Theory Into
Practice, Englewood Clifts, N. J., Prentice Hall.

Turban, E. \& Aronson, J E., (2001): Decision Support Systems and Intelligent Systems 6th edition, Prentice Hall, Upper Saddle River,NJ 